西榑彎の 3 症例

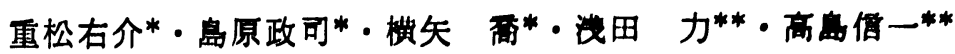

\title{
Three cases of facial prosthesis
}

\author{
Yusuke Shigematsu* - Masashi Shimahara* - Takashi Yokoya* \\ Chikara AsadA** Shinichi Takashima**
}

\section{鼓}

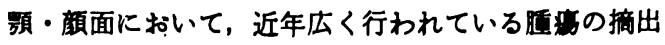
や，增加する交通事故なとによる外伤，そして徐々に增 加しているといわれる奇形なと，いろいろの原因によっ て, 頻, 顔面に生しる実質欠損は，その数を增している すのと思われる. これら久損の患者に与える影篅は，単 に発言障害や咀㛵障害などの機能的障害たけでなく，取 も大きいすのは，審美的障害であり，患者の精神的負担 は非常に大きい.そしてひいては，患者の社会復淿にと っても大きな問題である. 近年形成外科の発達により皮 间移植なと観血的手術による攸復の通用範囲がひろがり つつあるとはいらすのの, 久損が大きすぎるめや, 部 位的な問題のために，手術が不可能なことも少なくない， このような場合，非锶血的に，人工物によって久損部を 補填しようとする試みがなされてきている。この人工補 緅物による悠復は，その歴史は古く；瀬戸1によると， エジフトトのイラや，2 世紀ごろの中国やインドにす見 られたといら，中世に入ってもヨーロッパでは，金属や 皮革を用いて補緅を行った記録か戏っている.しかし近 代になってさらに進歩し，現代においては，とくに高分 子化学のめざましい発達で, いろいろの合成樹脂か開発 され，それらによって影・顔面補䋊も急速な進歩を見た。 今まで,アクリル系樹脂2), シリコン系樹脂3)()，ビニル 系樹脂(), を用いての頻・顔面補緅の報告がみられる. 今回私達は今まで用いられていないエボキシ系軟性榯脂 を用いて補経を行った．とくに皮成感の再現には，エポ キシの透明度のすぐれていることを利用し，従来他榯脂 で行われていたよらに, 表面から着色する方法をとらず に，裹面より着色して，表面に色をらき出させ，榯脂表

\footnotetext{
${ }^{*}$ 大阪医科大学口腔外科学教室 (主任 : 古川整夫助数授)

** ニッシソ株式会社 (京都)

* Department of Oral Surgery, Osaka Medical College.

- (Chief : Assist. Prof. Tetsuo Furukawa)

** Nissin Dental Products INC. (Kyoto)

受付 昭和 50 年 4 月 4 日
}

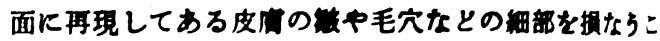

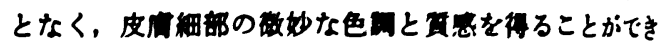
た.

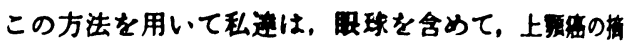

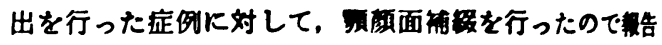
する.

\section{症计}

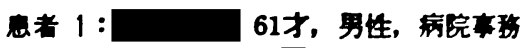

初 : 昭和46年10月旦

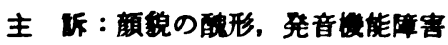

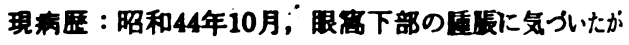

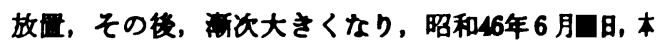
院耳科へ右上頙盘の診断のるとに入完, 同6月四，

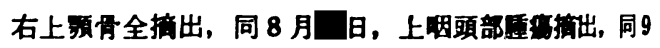

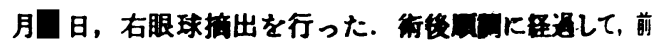
記主訴にて当科に稆介された。

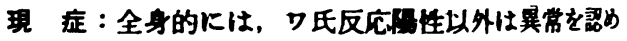
なかった，体格，栄筫は中等度，局所的には，面面ては，

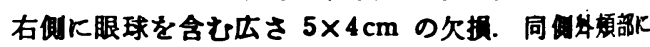

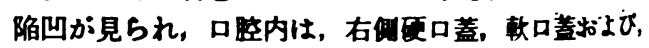

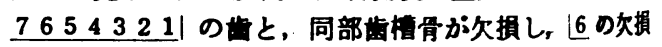
あ見られた.

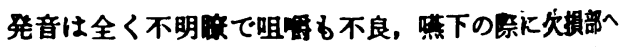
の食物の流入が見られた。

息者 2 ：林，男性，印剧菜

初昭和46年12月口日

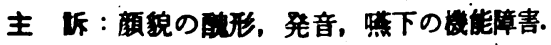

現病厢：昭和46年8月, 閉塞と左煩部の董脹下気门

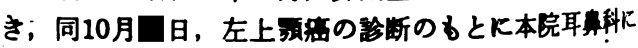
入院. 同10月回，左上䫘およひ左眼球の摘出を行うた。 その後㮌調に释過し前記主訴にて当科に稆介される.

現 症：全身的には，特記すべをことはながった。 で局所的には; 顔面では，左眼球の摘出のため眼简部，

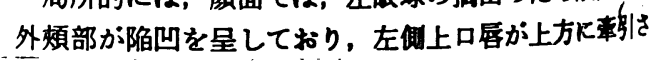


れていた，口腔内は，左侧上频骨と靯口蓝の一部が欠如 し11234567，の雨および同部歯槽骨も欠如してい t. 7654321

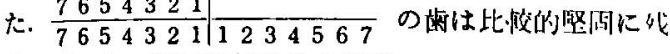
存していた。開口状態は約 1 啮指.

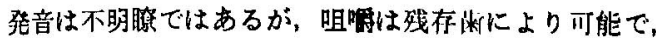
整下時に欠椇部への食物の流入が見られた。

\section{患者 3： 50 才。会社夏}

初喰：昭和48年 6 月 日

主 訴：顔貌の蠤形

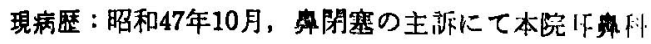
外来を訪れ，右上䫑癌の診断のもとに，同10月曰日，入

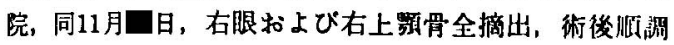
に程過し，当科にて口腔内欠損部の频絉緅を行い，昭和 48年 2 月日日, 軽快退院したが, 同 3 月日日, 闻発のた

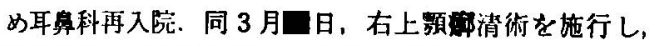
程過良好にて前記主訴にて当科に稆介される.

現 症：全身的には，特記すべきことはなかった，作 格、栄養㹥中等度。

局所的には，顔面で，右侧に眼球を含む公さ $5 \times 5$ $\mathrm{cm}$ の欠損が見られ，口腔内は，右侧硬口蓋，軟口蓋拧 よび $7654321 \mid$ の崡の久損と， 76543211 部の 橉槽骨の久損が見られた．なお頻補緅をすでに行ってい るため，発音，咀嚼は此較的良好であった（写真 1）.

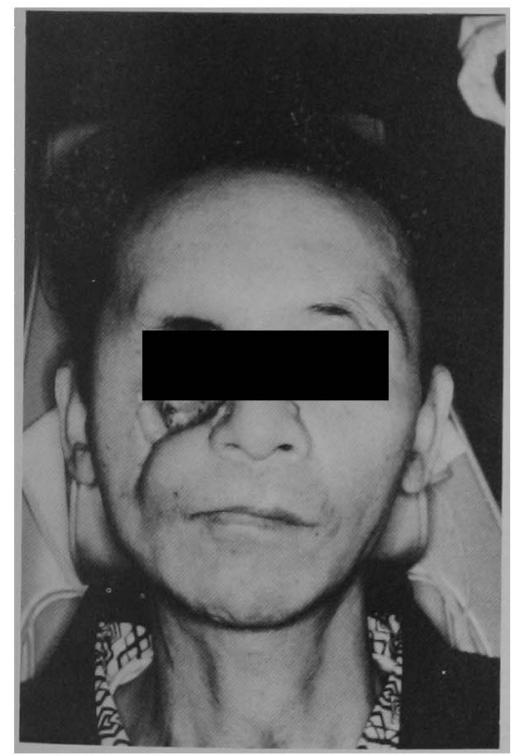

写真 1 症例 3 補槡前

補籺物の製作

\section{顔面の印象}

印象虫，できるだ静止無圧印象を必要とする，その

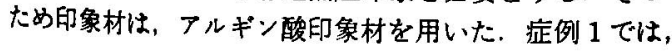

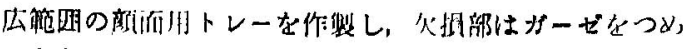

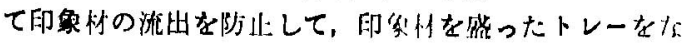
るべく圧を㞦えないよらに䫄面にすっていき，印像を行

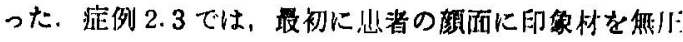

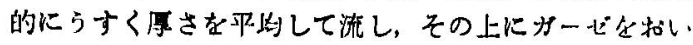
て印象忉を硬化させ，その後さらにその上に仿を浙し て固定して，一地としてとりだした（写真2）。

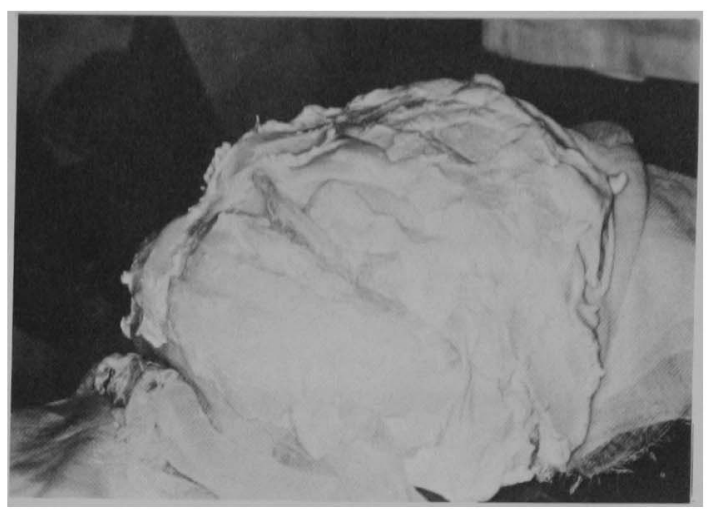

写真 2 顔面の印象採得

\section{義眼の選択}

健側の眼裂の大きさ，形などを測定し，患側の眼の大 きさ，形をきめた，症例1，2では既製の義眼から適当な るのを選択し，症例 3 では特別に南門家に，補緅処罚の 行いやすいよう．私達の希望む入れて作製してもらった。

模型上でのワックスによる形態回復

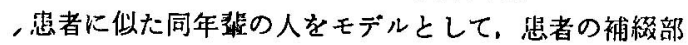
と同部の印象をシリコン印象材で採得し，その印象面に パラフィンワックスを約 $2 \mathrm{~mm}$ の厚さに流して，皮咸 の铍や凹凸，毛穴などの細部を印記し，そのワックスを 患者の石搞模型に圧接, 適合させ、ワックスに眼裂の部 分を開け修正する。 それに用意してある義眼を入れて， ワックスの状態で完成させる，その際皮府の細部の状隹 をつぶさないよらに注意する。

\section{人工皮膚の製作}

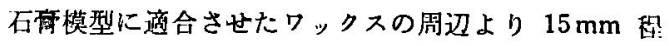
外周まで模型ごとシリコン印象材で印象を行ら，その印 象面に義腿をはずしたワックスをむとし，さらに襄面の 印象をシリコン印象材で行い.「合わせ型」をつくり, エポキシを流し込むための鋳型をつくる. 襄面の方には エボキシの流入口をつくる．このシリコンでできあがっ た鋳型に，透明度の高い皮席色の軟性エポキシを流し， 硬化させ，硬化後それを裏面より可及的に $1 \mathrm{~mm}$ 以下 にうすく削る.

表面は皮䖉の細部の触や毛穴が再現されて出来上が る.

\section{皮昰色の再現}

エポキシの基礎床は，基礎皮膚色が与えられているか， 

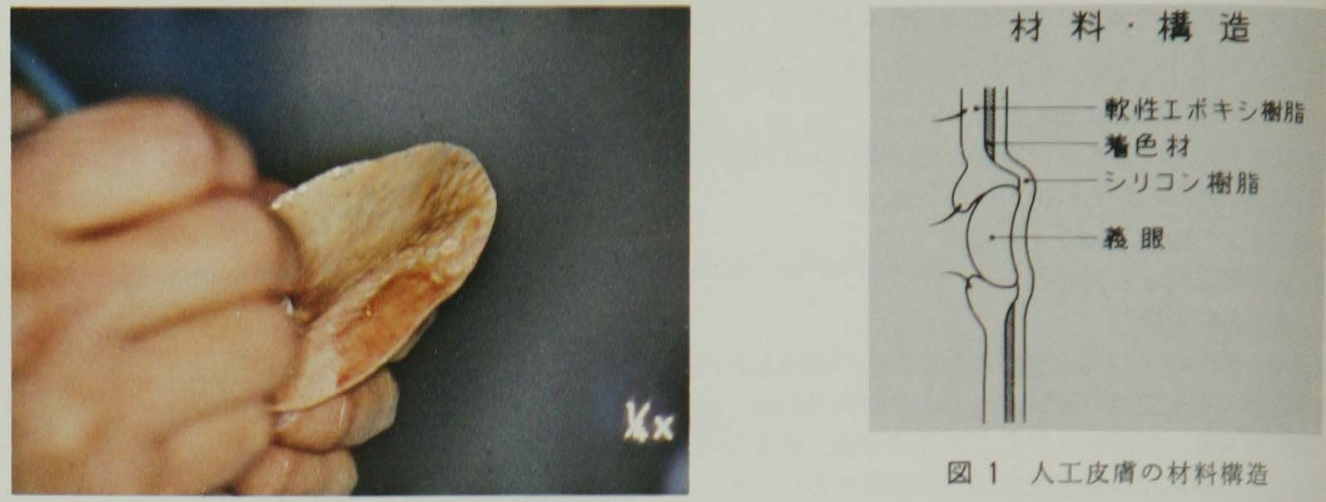

写真 3 エボキシ裹面より着色

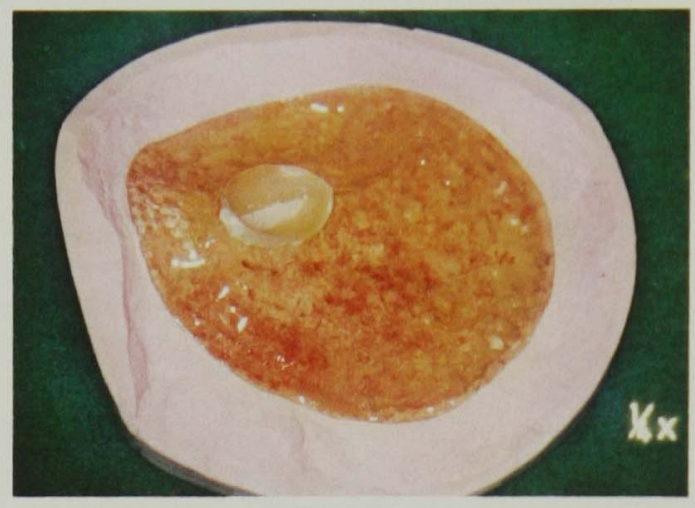

写真 4 着色完了したエポキシ䧶面

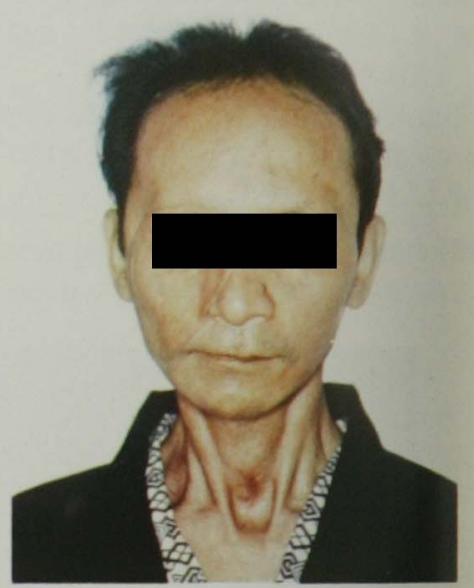

写真 8 症例 3 人工皮㲊の誡適

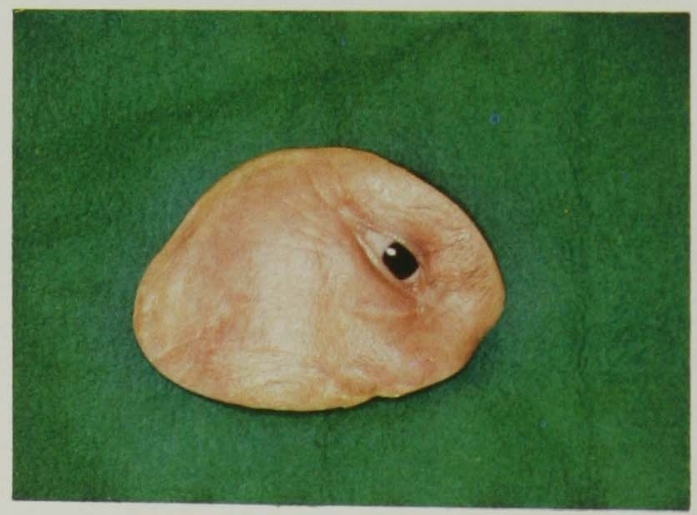

写真 5 義眼を接着した人工皮店

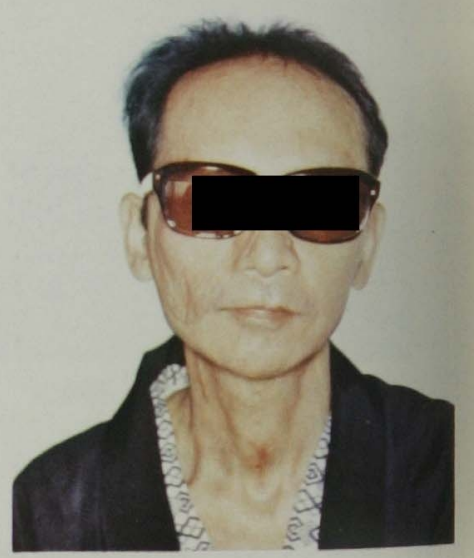

写真 9 症例 3 顔面補緅の完成 
より自然な皮虑色を再現するために，自然炕のるとで照 者の皮席を直接見ながら䇤で，囬面から著色忉で弁付け を行い透明度の高い軟性エポキシを通してらきださせる。 表面からは，皮庙の細部を損ならので畕色しない（写京 $3,4)$.

\section{義眼の接盖}

患者にまっすぐ前方を注視させ，健側の腿球と対比し ながら，最む自然な位膡で，義眼を夏面より僢間接着殽 でエポキシ基䂿床に接着する（写本 5 ）.

\section{皮虎接触面のシリコンによる被萑}

エポキシの迵面に着色仏が染布されているが，さらに この上にシリコン樹脂をらすく流して硬化させる（写市 6).

\section{まつ毛，まゆ毛の接莎}

一本づつ，エボキシ表面に穴をあけ，間接着䬉で植 えた。

保持装置の取り付け

症例 1 では，顔面欠損部が大きいのでひるを眼帶様に

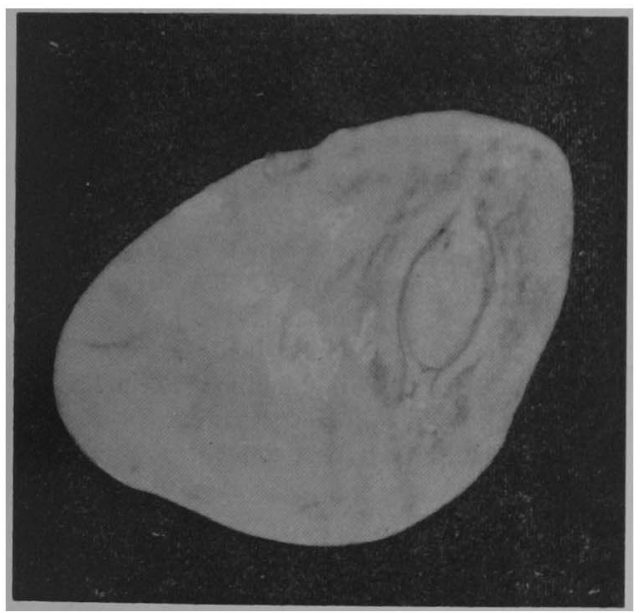

写真 6 裏面のシリコンによるコーディング

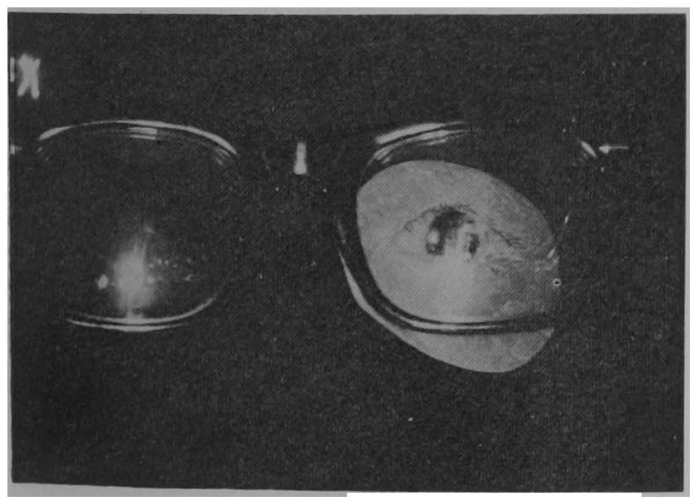

军真 7 眼 鏡に固 定

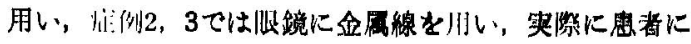

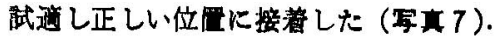

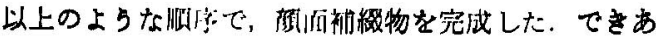

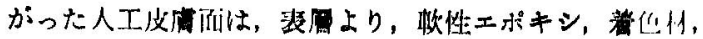
シリコンの三展より成り（图１），厚さは約 $2 \mathrm{~mm}$ であ

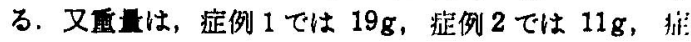
例 3 では $18 \mathrm{~g}$ である（写南8，9）。

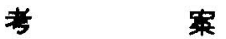

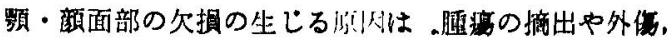

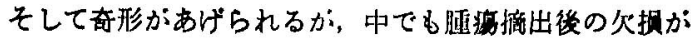

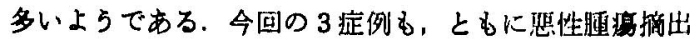
舁者であったしかしいかなる原因にせよ，靧・廎面部 の欠損は，機能的にも，寀美的にも障害をおこし，ひい ては患者におよはす精神的負担は大きい，

尰褯がいかに完全に摘出されたとしても，それは病因 が除去されたにすぎず，決して病人の治療の䅂了を意味 するものではないなぜなら病人の治療とは，病気を単 にな特すことではなく，社会的な環境の中で，意志をる った，それぞれ個性のある，人格をむつ人間を治療する ことであるからである6)，とくに悪性腫湶において，常 に再発の危険がとなら。これは現代医学の限界ですあ ろらが，しかし，手術によって生じた顔面の久椇に補緅 を行い，たとえ 1 週間でも，2 週間でる，患者の人間的 な，社会的な意欲をふるいたたせる一助になれば，影・ 顔面補緅の医療に扣ける意義は，大きな位眐を占めるる のと確信する。

印象採得は，できるたけ顔面広範聿の正確な印象を必 要とするが，奥野ら ${ }^{5)}$ は石育を用い, Brown ${ }^{7)}$ は $\mathrm{Hy}$ drocolloid 印象材を，顸戸ら ${ }^{2)}$ Rahn 5 $5^{8)}$ は私達と同様， アルギン酸印象材を用いている，方法すほ注同様でまま ず顔面に，アルギン酸印象材を，5すく均一に流し，そ の上を石市て固定する.この方法は石亭印象に比へてて,

1）とり报いが简単，2）患者の苦痛を㹩减できる，3） 皮成細部にまで詳細に印象ができる４4）压による印象 面の変形が少ないなどの利点をあげることができる.

材料については，今回私達の作製した補緅物は，外面 より，軟性エボキシ，着色材，そして皮底に触れる部分 は、シリコンといら三層より成っている，これら顔面補 槡の材料については，いろいろのるのが使用されており，

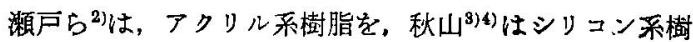
脂を，奥野らす)はビニル系樹脂を用いている．今回私達 は主をしてエポキシを用いているが，これは表層部に用 いて直接皮惯には接触しないが，しかし，あくまで組織 に対して為害作用のあるるのでは不適当である.エポ キシの生体に対する為害作用については，Kydd ${ }^{9)}$ によ るとエポキシの硬化肪として使われるアミン系の硬化剂

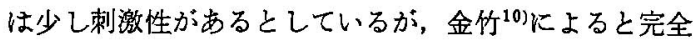
に重合したるのでは為害作用がなとされており，井 
上“11はこれを床用材料として応用し，また㙁科用充呮绪 としても広く応用されている，たからその安全性につい ては十分に使用でるすのと考えている，さらにこの他

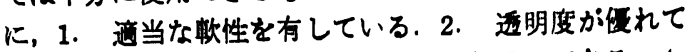
いて色付けが自由である．3. らすく柽国にできる．4. 保持装严やまつ毛なとの接着が容易である．5. 皮间細 部の触や毛穴まで再現が可能である，

などの特長を有している.

以上のことからも顔面補緅の人工皮应部の材料として

镸れたすのであると考える.

また直接皮后に接触する部には，シリコン榯脂を用い ているか，これの生体に対する為邫性については，従来 より樹脂中取も安全なすのとされており，川原 ${ }^{12)}$ ，灀 本 $^{19)}$ はシリコンの組織内埋入実䀶でも，期も生体反応の 少ないものであると言っている.すでに医学分野におい て，体内，体外ともに広く応用されており，皮间接触部 に最適の材料であると考える。

皮庙色の再現については，White (4)，澒戸(1)はアクリ ル系樹脂に基礎皮后色を与え, その上から着色を行って おり, Fonseca ${ }^{16)}$ はシリコンに同様表面より着色を行っ ている. 今回私達は軟性エポキシの适明度が俊れている ことを利用して，エポキシの基碗床に，基礎皮原色を与 えておいて，さらにその夜面より，明るい場所で，直接 患者の顔と対比させながら，筆で着色して表面にらきた させるよらにした.この方法によると，エポキシの表面 に与えられた，皮后の触や毛穴，凹凸などの細部を損な わず, 透明感も加え，より自然な皮庙感を再現すること ができた．またこれら着色材はエボキシとシリコンの间 に介在しているため值接空気とす接触せず，变色の機会 あ少ないのではないかと考えている.

また人工皮庙のエボキシ基礎床の製作過程において， それに自然の皮店感を再現するため患者に似た年格好の 人の同部の皮庙の印象を行って, それを患者の模型に移 しているが，できることなら，患者の術前の印象を採得 しておけば，より適合した皮庙面を再現できるのではな いか.

保持方法については，眼鏡に求めているすの 2 ()) が多 いか，奥野ららは，口腔内の頻補緅物に，アタッチメン 卜を考案して，それで連結し，互いに保持を求めている。 私達は，症例 1 では，ひもを眼帯様に用いて顔に結びつ けており，症例2，3では，眼鏡に金属線を用いて接着， 保持を求めた。しかし症例 1 です，人工皮庙部が軽量で あること、エポキシ基礎床の接着が強固で容易なことか ら，十分に眼鏡に保持を求められたと考えている.

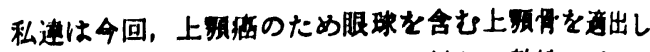

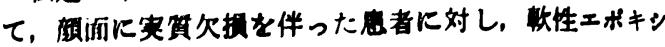

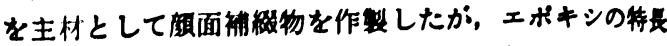

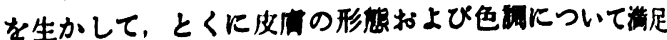
のゆく綃果をらることがでをた。

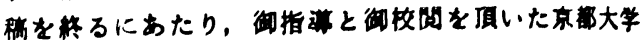

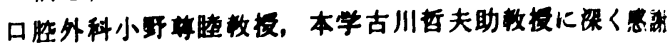
致します。

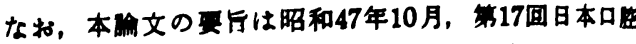

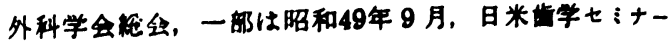

（京都）において発衰した。

\section{文塥}

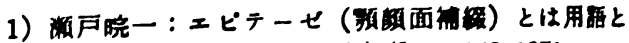

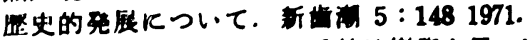

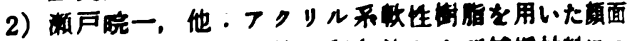

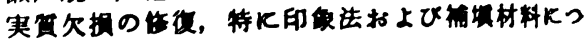
いて。. 口科洼 $20: 7791971$.

3）秋山太一郎：ジィチルボリンロキサンの医学庆用 の基本. 形成外科 $3: 881960$.

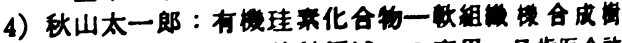

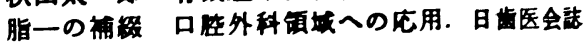
$10: 570,1958$.

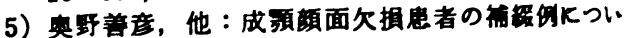

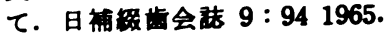

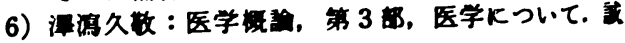
信费局，真京 1960 .

7) Brown, K. E. : Fabrication of ear prosthesis. J. Prosthet Dent 21 : 6701969.

8) Rahn, A. O., Boucher, L. J. : Maxillofacial Prosthetics Principles and Concepts. W.B. Saunders Co. Philadelphia 1970, p. 151.

9) Kydd, W. L. : Toxicity evaluation of diethylenetriamine. J Dent Res $39: 461960$.

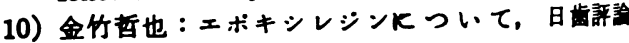
$298: 9161967$.

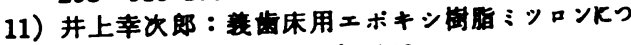
いて。目齿材会誌 4:i 1959 .

12）川原春幸：生物理工学からみた常温重合洁脂の医 学的応用. 齿科時犚 $337: 81960$.

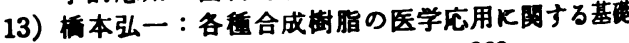
的研究。京都府医大誌 $68: 4711960$.

14) White, G. E. : A new flexible material for facial prosthesis. Dent Tech 16, 1981970.

15）湎戸晥一：額顔面欠損に対するエピテービ用材林 Palamed の变色に间す万色彩科学的研究. 口病 誌 $38: 121971$

16) Fonseca, E. P. : The importance of form, characterization and retention in facial prosthesis. J Prosth Dent 16 : 3381966. 